\title{
Reduction in Plasma Protein Does Not Affect Body Water Content in Fetal Sheep
}

\author{
ALICIA A. MOÏSE, ALFRED L. GEST, PETER H. WEICKMANN, AND HARILYN W. MCMICKEN
}

Department of Pediatrics, Baylor College of Medicine, Houston, Texas 77030

\begin{abstract}
We performed this study to determine if isolated hypoproteinemia and low colloid osmotic pressure cause formation of fetal edema. We successfully operated on six sets of twin fetal sheep at $114 \mathrm{~d}$ gestation to insert catheters into arteries and veins of both fetuses, allowing us to chronically perform partial exchange transfusions. One twin underwent protein reduction by repeated partial exchange transfusion over $3 \mathrm{~d}$, and the other twin underwent simultaneous sham procedures. We removed an average of $18 \mathrm{~g}$ of protein, causing a $41 \%$ decrease in plasma protein concentration and a $44 \%$ decrease in colloid osmotic pressure. Vascular pressures, heart rate, hematocrit, plasma osmolarity, arterial $\mathrm{pH}$, and arterial $\mathrm{PO}_{2}$ were not affected by protein reduction or by sham procedure, whereas $\mathrm{PCO}_{2}$ increased by a small amount in both groups. At autopsy, none of the fetuses in either group were edematous. Measurements of total body water by the wet to dry method, chloride space, and amniotic and allantoic fluid volumes were similar in both groups. We conclude that hypoproteinemia of a short duration does not affect the body water content of fetal sheep. (Pediatr Res 29: 623626,1991 )
\end{abstract}

Hypoproteinemia with decreased colloid osmotic pressure is frequently proposed as one of the causes of hydrops fetalis. However, not all infants with hypoproteinemia and decreased colloid osmotic pressure become hydropic. Hydrops is uncommon in infants with congenital nephrosis and congenital analbuminemia $(1,2)$. In addition, Baum and Harris (3) found low colloid osmotic pressures in babies with erythroblastosis but noted similar colloid osmotic pressures in both hydropic and nonhydropic erythroblastotic infants. Moreover, there is also evidence that fetal hydrops occurs in the absence of hypoproteinemia. Gest et al. (4) found that fetal lambs develop hydrops secondary to atrial pacing before any change in plasma protein concentration occurs.

We performed this study to answer the following question: Does hypoproteinemia alone lead to edema and hydrops in the fetus? We designed this study to produce hypoproteinemia and decreased colloid osmotic pressure without changing vascular pressures or capillary permeability, other factors possibly contributing to edema formation in the fetus.

\section{MATERIALS AND METHODS}

Surgical methods. We successfully operated on six pairs of twin fetal sheep at $114 \mathrm{~d}$ gestation. For anesthesia, we injected $30 \mathrm{mg}$ of tetracaine hydrochloride into the epidural space and

Received July 25, 1990; accepted January 18, 1991.

Correspondence and reprint request: Alfred L. Gest, M.D., Department of Pediatrics, Baylor College of Medicine, One Baylor Plaza, Houston, TX 77030.

Supported by grants from the American Heart Association, Texas Affiliate American Heart Association, National Center. intermittently administered ketamine hydrochloride i.v. for sedation. We exposed the uterus through a midline abdominal incision, located a fetal hindlimb, and withdrew it through a small uterine incision. After injecting $1 \%$ lidocaine s.c. into the lateral surface of the limb just below the hock, we isolated the artery and vein by blunt dissection and threaded polyvinyl catheters into the aorta and vena cava. We then returned the hindlimb to the uterine cavity.

Next, we located the fetal head and neck and withdrew them through the uterine incision. We injected $1 \%$ lidocaine s.c. into the fetal neck, then we isolated the carotid artery and jugular vein by blunt dissection and inserted polyvinyl catheters into these vessels. To measure amniotic fluid pressure, we sutured a catheter to the skin overlying the neck. We then returned the fetal head and neck to the uterine cavity and closed the uterine incision. Next, we performed the same surgical procedures in the other twin and, upon completion, closed the ewe's abdominal incision. We exteriorized the catheters through a s.c. tunnel to a plastic pouch on the ewe's flank. For postoperative analgesia, we gave the ewes nalbuphine hydrochloride (Nubain; Du Pont Multisource Products Division, Garden City, NY); for infection prophylaxis, we injected penicillin (600 000 units) and kanamycin $(50 \mathrm{mg})$ into the amniotic cavity after surgery and daily thereafter. We also treated the ewes with intramuscular penicillin and dihydrostreptomycin (Combiotic; Pfizer Inc., Agriculture Division, New York, NY; $3 \mathrm{~mL}$ ) daily after surgery. All ewes recovered at least $5 \mathrm{~d}$ before we conducted any studies.

Experimental methods. During the baseline period and hourly during the experiment, we measured arterial, venous, and amniotic fluid cavity pressures in each twin using Statham P23 db strain gauge manometers and recorded the pressures on an eightchannel amplifier recorder (Gould, Inc., Instruments Division, Cleveland, $\mathrm{OH}$ ). We obtained the heart rate from the phasic aortic pressure tracing and referenced vascular pressures to amniotic fluid cavity pressure by manually subtracting amniotic fluid cavity pressure from each recorded vascular pressure. Also, we measured the $\mathrm{pH}$ and partial pressures of $\mathrm{O}_{2}$ and $\mathrm{CO}_{2}$ in arterial blood using a Corning $178 \mathrm{pH}$ blood gas analyzer (Corning Medical and Scientific, Medfield, MA). During a baseline period and at 2-h intervals during the protein and sham reduction process, we measured colloid osmotic pressure using a Wescor colloid osmometer (Wescor Inc., Logan, UT), whole blood osmolality by freezing point depression using an Osmette A automatic osmometer (Precision Systems, Inc., Sudbury, MA), plasma protein concentration by the Biuret method, and hematocrit.

After the baseline measurements, we began removing protein from one of the twins over a $3-d$ period. For protein reduction, we removed a $20-\mathrm{mL}$ aliquot of blood, centrifuged it, removed the plasma, and discarded it. Then we reconstituted the red blood cells to their original volume with normal saline and returned the resulting mixture to the fetus. We repeated this process 10 times each day for approximately $9 \mathrm{~h}$ over $3 \mathrm{~d}$. Simultaneously, we performed a sham reduction in the control twin by removing, 
and then reinfusing without centrifugation, the same volume of blood as in the experimental twin.

Postmortem studies. After partial exchange on the 3rd day of the experiment, we killed the ewe and the twin fetuses. After killing the fetuses, we collected the amniotic and allantoic fluid of each and measured the volume directly. We then weighed each fetus and dried it to a constant weight in a $100^{\circ} \mathrm{C}$ oven to determine total body water by the wet to dry method. Then we ground each fetus with a mortar and pestal, mixed the powder in a Waring blender to produce a homogeneous slurry, redried the resultant paste to a constant weight in a $100^{\circ} \mathrm{C}$ oven, removed the wool with a sieve, and collected an aliquot of the well-mixed powder to determine the chloride space of the fetus according to the method of Cheek et al. (5). Briefly, we determined the chloride space by dividing the total body chloride (the chloride concentration of the above aliquot times the dry weight of the fetus) by the concentration of chloride in the serum ultrafiltrate. We obtained the serum ultrafiltrate concentration of chloride by correcting the serum chloride concentration for serum water and Donnan equilibrium using the following equation:

$$
(\mathrm{Cl})_{\mathrm{ef}}=(\mathrm{C} 1)_{\mathrm{s}} /(0.93 \times 0.95)
$$

where $(\mathrm{C} 1)_{\mathrm{cf}}$ is the amount of chloride in the serum ultrafiltrate, $(\mathrm{C} 1)_{\mathrm{s}}$ is the chloride concentration in the serum, 0.93 is the correction for serum water ( $930 \mathrm{~mL}$ per liter of water), and 0.95 is the Donnan factor.

Statistical methods. We used the paired $t$ test to determine if the values obtained on the last day of the study were different from the baseline. We used an unpaired $t$ test to compare the measurements of total body water and chloride space between the control and protein depleted fetuses. We expressed all data as mean \pm SEM and considered $p$ values $<0.05$ statistically significant.

Using a power analysis, our data suggest that we would be able to detect a difference in body water content between control and protein reduced fetuses of $2.4 \%$ or $50 \mathrm{~mL}$ with $80 \%$ accuracy at the $p<0.05$ level.

This protocol was reviewed and approved by the Baylor College of Medicine Animal Protocol Review Committee.

\section{RESULTS}

We studied six twin fetal sheep at approximately $119 \mathrm{~d}$ of gestation. We removed an average of $18 \mathrm{~g}$ of protein from each of the protein reduced twins over a 3 -d period. Colloid osmotic pressure decreased daily in a step-like manner with the value at the beginning of reduction each day being less than the preceding day's initial value. Approximately $15 \mathrm{~h}$ elapsed between the end of protein reduction one day and the beginning of protein reduction the next day (Fig. 1). We observed a similar pattern for plasma protein concentration. Overall protein reduction resulted in a $41 \%$ decrease in plasma protein concentration and a $44 \%$ decrease in colloid osmotic pressure (Table 1 ). Sham reduction did not affect plasma protein concentration or colloid osmotic pressure.

Although neither protein reduction nor sham reduction affected heart rate, vascular pressures, hematocrit, plasma osmolality, arterial $\mathrm{pH}$, or arterial $\mathrm{PO}_{2}$, both procedures resulted in a small but significant increase in arterial $\mathrm{PCO}_{2}$ (Table 2).

At autopsy, none of the fetuses in either group appeared edematous, and none had measurable amounts of peritoneal or pleural fluid. Control fetuses weighed $2.1 \pm 0.7 \mathrm{~kg}(\mathrm{SD})$ and protein-reduced fetuses weighed $1.8 \pm 0.4 \mathrm{~kg}$. The placentas of control fetuses weighed $427 \pm 110 \mathrm{~g}$ (SD), and the placentas of protein-reduced fetuses weighed $424 \pm 83 \mathrm{~g}$. Measurements of body water and chloride space as a percentage of body weight were virtually identical between the two groups, as were measurements of amniotic and allantoic fluid volume (Table 3 ).

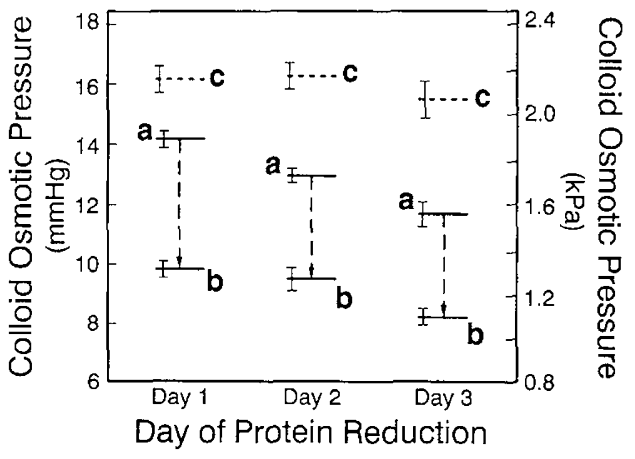

Fig. 1. Colloid osmotic pressure at the beginning $(a)$ and end $(b)$ of each day of protein reduction, and at the end of reinfusion in the control (sham) twin $(c)$. Colloid osmotic pressure decreases with protein reduction in a stepwise manner. Although colloid osmotic pressures at the beginning of each day are higher than the preceding day's final values, they never attain the initial values of the previous day. Colloid osmotic pressure does not change in the control (sham) twin. Error bars represent SEM.

Table 1. Effect of protein reduction upon plasma protein concentration and colloid osmotic pressure*

\begin{tabular}{ccc}
\multicolumn{3}{c}{ concentration and colloid osmotic pressure } \\
\hline & $\begin{array}{c}\text { Plasma protein } \\
\text { concentration } \\
(\mathrm{g} / \mathrm{L})\end{array}$ & $\begin{array}{c}\text { Colloid osmotic } \\
\text { pressure } \\
(\mathrm{kPa})\end{array}$ \\
\hline Control & $35 \pm 1$ & $2.16 \pm 0.11$ \\
Baseline & $34 \pm 1$ & $2.08 \pm 0.15$ \\
Last day & $34 \pm 2$ & $1.88 \pm 0.09$ \\
Reduced & & $1.09 \pm 0.08 \dagger$ \\
Baseline & $22 \pm 2 \dagger$ & . \\
Last day &
\end{tabular}

$*$ Values are mean \pm SEM. Conventional units: control twin baseline colloid osmotic pressure $16.2 \pm 0.8 \mathrm{~mm} \mathrm{Hg}$, last day colloid osmotic pressure $15.6 \pm 1.1 \mathrm{~mm} \mathrm{Hg}$; reduced twin baseline colloid osmotic pressure $14.1 \pm 0.7 \mathrm{~mm} \mathrm{Hg}$, last day colloid osmotic pressure $8.2 \pm 0.6$ $\mathrm{mm} \mathrm{Hg}$.

$\uparrow$ Significant difference from baseline; $p<0.01$.

\section{DISCUSSION}

We found that protein reduction by partial exchange transfusion was an effective way of lowering both plasma protein concentration and colloid osmotic pressure in the fetal lamb. In our experiments, both plasma protein concentration and colloid osmotic pressure progressively decreased over the $3 \mathrm{~d}$ of protein reduction. Although both plasma protein concentration and colloid osmotic pressure rose toward the baseline value during the ensuing $15 \mathrm{~h}$ when partial exchanges were not being performed, they never reached the beginning values of the previous day. Colloid osmotic pressures were nearly $50 \%$ of their beginning values by the $3 \mathrm{rd}$ day of protein reduction (Fig. 1). In fact, the reduction in colloid osmotic pressure that we measured was lower than that measured by Baum and Harris (3) in infants with severe hydrops. In our studies, however, the reduced plasma protein concentration and the decreased colloid osmotic pressure were not sufficient to produce edema in any of the fetal sheep studied. Normally, ex utero without a placenta, the rate of transvascular fluid filtration is equal to the rate of removal of filtered fluid by the lymphatic system, and edema only occurs when the rate of filtration exceeds the rate of removal. However, in utero the presence of the placenta provides another mechanism for fluid transfer and removal, usually with net fluid flux occurring from mother to fetus. Therefore, for hydrops fetalis to develop, not only must the rate of transvascular fluid filtration exceed the rate of lymphatic removal of fluid, but also the net 
Table 2. Effect of protein reduction on arterial blood gas tensions, vascular pressures, hematocrit, and plasma osmolality*

\begin{tabular}{|c|c|c|c|c|c|c|c|}
\hline & $\mathrm{pH}$ & $\mathrm{PaO}_{2}(\mathrm{kPa})$ & $\mathrm{PaCO}_{2}(\mathrm{kPa})$ & $P_{\text {aorta }}(\mathrm{kPa})$ & $P_{i v c}(\mathrm{kPa})$ & $\mathrm{HCT}$ & $\begin{array}{l}\text { Osmolality } \\
(\mathrm{nmol} / \mathrm{kg})\end{array}$ \\
\hline \multicolumn{8}{|l|}{ Control } \\
\hline Baseline & $7.38 \pm 0.01$ & $3.33 \pm 0.27$ & $6.27 \pm 0.27$ & $5.20 \pm 0.40$ & $0.40 \pm 0.13$ & $0.29 \pm 0.02$ & $291 \pm 3$ \\
\hline Last day & $7.37 \pm 0.01$ & $3.33 \pm 0.27$ & $6.93 t \pm 0.27$ & $5.20 \pm 0.27$ & $0.40 \pm 0.13$ & $0.26 \pm 0.02$ & $293 \pm 3$ \\
\hline \multicolumn{8}{|l|}{ Reduced } \\
\hline Baseline & $7.36 \pm 0.01$ & $3.47 \pm 0.27$ & $6.27 \pm 0.27$ & $5.47 \pm 0.27$ & $0.27 \pm 0.13$ & $0.30 \pm 0.02$ & $292 \pm 2$ \\
\hline Last day & $7.35 \pm 0.01$ & $3.33 \pm 0.27$ & $6.93 \dagger \pm 0.27$ & $5.07 \pm 0.40$ & $0.40 \pm 0.13$ & $0.27 \pm 0.02$ & $297 \pm 3$ \\
\hline
\end{tabular}

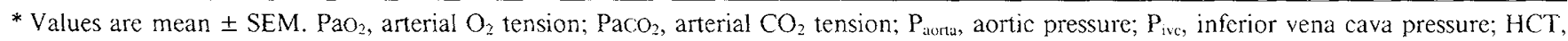
hematocrit. Conversion: $1 \mathrm{kPa}=7.5006$ torr.

Table 3. Effect of protein reduction upon body water, chloride space, and amniotic fluid volume*

\begin{tabular}{lccc}
\hline & $\begin{array}{c}\text { Body water } \\
(\% \text { body } \\
w \mathrm{t})\end{array}$ & $\begin{array}{c}\text { Chloride space } \\
(\% \text { body wt) }\end{array}$ & $\begin{array}{c}\text { Amniotic } \\
\text { fluid volume } \\
(\mathrm{L})\end{array}$ \\
\hline Control twin & $83.4 \pm 0.6$ & $54.6 \pm 2.5$ & $0.349 \pm 0.144$ \\
Reduced twin & $83.1 \pm 0.6$ & $55.5 \pm 1.8$ & $0.361 \pm 0.154$ \\
\hline
\end{tabular}

* Values are mean \pm SEM.

flux of fluid across the placenta from mother to fetus must increase. In similar experiments in newborn lambs, Hazinski et al. (6) showed that a $38 \%$ reduction in plasma protein concentration resulted in a $58 \%$ increase in the rate of fluid filtration into the lung. In all likelihood, the reduction of colloid osmotic pressure in our experiments resulted in an increased rate of transvascular fluid filtration. Even so, none of the fetuses in our study developed edema, suggesting that the rate of lymphatic removal must have increased to an equal degree. Our results are similar to those of Hazinski et al. (6), who found that hypoproteinemia did not result in fluid accumulation in the lung even when microvascular pressures were increased by inflation of a balloon in the left atrium. Our results are also similar to those of Pearson et al. (7), who depleted a fetal lamb of protein by chronic drainage of thoracic duct lymph and noted no edema at the time of delivery.

Hydropic fetuses have an exaggerated rate of fluid transfer from the maternal to the fetal compartment, reflected by an expanded fetal extracellular fluid space. Intuitively, fetal hypoproteinemia might create a greater osmotic gradient across the placenta, favoring the transfer of fluid from the fetal to the maternal compartment in an attempt to restore the fetal plasma osmotic pressure toward normal. In this respect, hypoproteinemia would actually serve a protective role, working against the development of hydrops. Evidence for the reversal of normal maternal fetal fluid flux exists in rabbits: when an osmotic gradient was created across the placenta by infusion of mannitol into the maternal circulation, there was a $2-4 \%$ decrease in fetal body water content at all stages of gestation with equal proportions of the loss coming from the intracellular and the extracellular fluid compartments (8). It is difficult to implicate flow of water across the placenta from fetus to mother in our study inasmuch as the protein-reduced fetus was not dehydrated and had total body water, chloride space, and amniotic fluid volume measurements virtually identical to the control fetus. Although we did not measure maternal plasma protein concentrations, we doubt that we could have detected a decrease because the volume of water transferred across the placenta from fetus to mother would be small relative to the volume of the maternal vascular space.

To date, only two ways have been described for producing hydrops in fetal lambs. The first was reported by Andres and Brace (9) and involves ligation and resection of a segment of the thoracic duct. Provided that the segment removed is long enough to prevent recannulation, this maneuver consistently results in fetal edema and suggests that impairment of lymphatic drainage alone is sufficient to produce hydrops. The second was reported by our laboratory and others and involves rapid atrial pacing (greater than 300 beats $/ \mathrm{min})(4,10,11)$. This technique invariably increases right atrial pressure and presumably the rate of transvascular fluid filtration. However, recent data from Brace (12) has shown that increases in lymph catheter outflow pressure, similar to the right atrial pressure seen with atrial pacing, aiso decrease the rate of lymph flow in the thoracic duct of the fetal lamb. Therefore, in this model of hydrops, edema appears to result from a combination of increased transvascular fluid filtration and impaired lymphatic function. Hypoproteinemia appears to develop later as a secondary, dilutional event and is of relatively small magnitude.

The duration of diminished protein concentration and protein osmotic pressure in our study was relatively brief, lasting only 3 $\mathrm{d}$, and the minimum value for plasma protein concentration occurred only during the 3 rd day of the study. Our study does not address whether or not protein reduction of a greater duration or magnitude would have caused more water accumulation by the protein-reduced fetus. There are, however, reasons to believe that this would not occur. We would expect that plasma protein concentration and interstitial protein concentration would reach equilibrium in situations in which the reduction in protein was of both greater duration and magnitude, equalizing the osmotic Starling forces across the fetal capillary membranes. Furthermore, infants with congenital nephrosis and congenital analbuminemia rarely have hydrops at birth, although they have been subjected to low plasma protein concentrations in utero for prolonged periods of time $(1,2)$. Additionally, at least in cases of fetal sheep with supraventricular tachycardia simulated by atrial pacing, edema forms quickly within $15 \mathrm{~h}$ of the onset of pacing and develops before the appearance of hypoproteinemia (4).

In conclusion, a reduction of plasma protein and colloid osmotic pressure occurring over $3 \mathrm{~d}$ does not affect the body water content of fetal sheep. If this degree of hypoproteinemia and decreased colloid osmotic pressure increases the rate of transvascular fluid filtration, then for body water content not to be increased, the fetal hypoproteinemia must lead to a decrease in or a reversal of the net rate of fluid transfer from the maternal to the fetal compartment, or the lymphatic system must effectively return the excess filtered fluid to the fetal vascular space.

\section{REFERENCES}

1. Hallman N, Norio R, Rapola J 1973 Congenital nephrotic syndrome. Nephron 11:101-110

2. Cormode EJ, Lyster DM, Israels S 1975 Analbuminemia in a neonate. $J$ Pediatr 86:862-867

3. Baum JD, Harris D 1972 Colloid osmotic pressure in crythroblastosis fetalis. Br. Med J 1:60l-603

4. Gest AL, Hansen TN, Moïse AA. Hartlcy CJ 1990 Atrial tachycardia causes hydrops in fetal lambs. Am J Physiol 258:H1159-H1163

5. Cheek DB, West CD, Golden CC 1957 The distribution of sodium and chloride and the extracellular fluid volume in the rat. J Clin Invest 37:340-351

6. Hazinski TA, Bland RD, Hansen TN, Sedin EG, Goldberg RB 1986 Effect of hypoproteincmia on lung fluid balance in awake newborn lambs. J Appl Physiol 61:1139-1148 
7. Pearson LD, Simpson-Morgan MW, Morris B 1976 Lymphopoiesis and lymphocyte recirculation in the sheep fetus. J Exp Med 143:167-186

8. Bruns PD, Linder RO, Drose VE, Battaglia F 1963 The placental transfer of water from fetus to mother following the intravenous infusion of hypertonic mannitol to the maternal rabbit. Am J Obstet Gynecol 86:160-167

9. Andres RL, Brace RA 1990 The development of hydrops fetalis in the ovine fetus after lymphatic ligation or lymphatic incision. Am J Obstet Gynecol $162: 1331-1334$
10. Stevens DC, Hilliard JK, Schreiner RL, Hurwitz RA, Murrell R, Mirkin LD, Bonderman PW Nolen PA 1982 Supraventricular tachycardia with edema, ascites, and hydrops in fetal sheep. Am J Obstet Gynecol 142:316-322

11. Nimrod C, Davies D, Harder J, Iwanicki S, Kondo C, Takahashi Y, Maloney $J$, Persaud D, Nicholson S 1987 Ultrasound evaluation of tachycardiainduced hydrops in the fetal lamb. Am J Obstet Gynecol 157:655-659

12. Brace RA 1989 Effects of outflow pressure on fetal lymph flow. Am J Obstet Gynecol 160:494-497

\section{Announcement}

\section{Annual Meeting of the European Society for Pediatric Research 1991}

The European Society for Pediatric Research (ESPR) will hold its next meeting in Zürich, Switzerland, September 1-4, 1991. The European Society of Pediatric Allergy and Clinical Immunology and the European Society of Magnetic Resonance in Neuropediatrics will join the ESPR. Satellite postgraduate courses and a symposium will be organized by these two societies on September 1 and September 5.

The main topics of the ESPR meeting are: therapeutic interventions in immune-mediated diseases, connective tissue, energy metabolism, and circulation of the neonatal brain.

For information, contact: Gabriel Duc, University Hospital of Zürich, Frauenklinikstrasse 10, ZH-8091 Zürich, Tel. + 41125553 40, Telefax + 4112554442. 